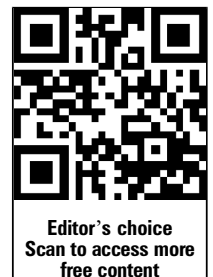

\section{Correspondence to}

Luke David Rostill, Wadham College, University of Oxford, Parks Road, Oxford OX1 3PN, UK; luke.rostill@law.ox.ac.uk

Received 1 March 2013 Accepted 14 March 2013 Published Online First 10 April 2013
To cite: Rostill LD. J Med Ethics 2014;40:14-18.

\title{
The ownership that wasn't meant to be: Yearworth and property rights in human tissue
}

\author{
Luke David Rostill
}

\section{ABSTRACT}

This paper is concerned with the English Court of Appeal's decision in Yearworth v North Bristol NHS Trust that six men had, for the purposes of their claims against the trust, ownership of the sperm they had produced. The case has been discussed by many commentators and most, if not all, of those who have discussed the case have claimed or assumed that the court held that the claimants had property rights in the sperm they had produced. In this paper, I advance an interpretation of the case that does not regard the court as deciding that the men had property rights (in the narrow sense of that term) in the sperm they had produced. On this view, the 'ownership' that the Court of Appeal purported to vest in each of the men was not a right in rem, a right 'binding the world'. If this is so, it is perhaps unsurprising that some scholars, evaluating the success of the court's reasoning as a justification for vesting the claimants with property rights, have found it to be unsatisfactory.

The English Court of Appeal's decision in Yearworth $v$ North Bristol NHS Trust that six men had, for the purposes of their claims against the trust, ownership of the sperm they had produced, has been described as a 'landmark'. ${ }^{2}$ Many of those who have discussed the case have claimed or assumed that the court held that the claimants had property rights in the sperm they had produced (ref. ${ }^{2}$, p.466; refs. ${ }^{3-5}$ ). In this paper, I advance an interpretation of the court's judgment that does not regard the court as deciding that the men had property rights (in the narrow sense of that term) in the sperm they had produced. On this view, the 'ownership' that the Court of Appeal purported to vest in each of the men was not a right 'binding the world'. It was not, in other words, what lawyers would call a right in rem. If this is so, it is perhaps unsurprising that some scholars, evaluating the success of the court's reasoning as a justification for vesting the claimants with property rights, have found it wanting.

\section{THE YEARWORTH CASE: FACTS, DECISION AND REASONING}

Facts and decision

Six men decided, after being diagnosed with cancer, to undergo a course of chemotherapy treatment. The men, having been advised that such treatment could damage their fertility, provided samples of their semen for frozen storage at one of the defendant trust's hospitals. The samples, while in storage at the hospital and before any attempt had been made to use them, thawed because there was an insufficient amount of liquid nitrogen in the tanks in which they were stored. The men's actions against the trust proceeded on the basis that the sperm had perished irretrievably. The men claimed that as a result of the loss of their sperm they suffered a psychiatric injury, namely, a mild or moderate depressive disorder, or, in one case, mental distress. The defendant conceded that it owed each claimant a duty to take reasonable care of the sample(s) he had produced and that it had violated that duty. But the trust denied liability. It submitted that the loss of the sperm constituted neither personal injury to the men nor damage to their property and that, therefore, it did not qualify as the sort of damage that is a necessary constituent of an action in negligence. Judge Griggs, in determining the four preliminary issues that the district judge had identified, agreed with these submissions. On the claimant's appeal against Judge Griggs' determination of the preliminary issues, the Court of Appeal upheld Judge Grigg's view that the damage to the sperm did not in itself constitute a personal injury to the men, but allowed the claimants' appeal. The court held that each man had ownership of or a possessory title to the sperm he had produced for purposes of his claims against the trust. It also held that there had been a gratuitous bailment of the sperm by the claimants to the defendant and, subject to certain factual issues yet to be determined, that the defendant was liable for psychiatric injury or mental distress consequent upon breach of bailment. ${ }^{i}$ This paper is concerned with the court's conclusion that the men had 'ownership' of the sperm (for the purposes of their claims) and with the reasoning by which that conclusion was reached.

\section{The court's reasoning}

In relation to the claims in negligence for damage to or loss of property, the claimants and the defendant, and Judge Griggs at first instance and their Lordships in the Court of Appeal, accepted or proceeded on the basis that the applicable rule was that stated by Lord Brandon in his speech in Leigh o Sullivan Ltd v Aliakmon Shipping Co Ltd: ${ }^{\text {ii }}$

${ }^{i}$ Very roughly, a bailment exists where one person is voluntarily in possession of goods belonging to another.

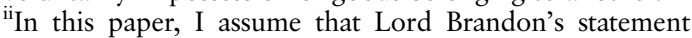
adequately reflects the law. The law on this matter is complicated, but the complications can be ignored for present purposes. 
[I]n order to enable a person to claim in negligence for loss caused to him by reason of loss of or damage to property, he must have had either the legal ownership of or a possessory title to the property concerned at the time when the loss or damaged occurred... ${ }^{6}$

Accordingly, one preliminary issue that the district judge had identified was 'whether the sperm was the property of the men'. Before Judge Griggs, this issue was divided by counsel into two questions: (1) Is a substance such as sperm, generated by the body but removed from it, capable of being owned? (2) If so, have the provisions of the Human Embryology and Federalisation Act 1990 eliminated or circumscribed, in relation to live human gametes (sperm and unfertilised eggs), so many of the rights normally incidental to ownership as to remove their status at common law as capable of being owned? The fact that something is capable of being owned does not entail that a particular person is capable of owning it, nor that any person has ownership of it. So it would seem that there are other questions that should have been answered in the affirmative in order for the claimants to have satisfied the requirements of the rule stated by Lord Brandon: (3) were the men capable of 'owning' the sperm? (4) Did each of the men have 'ownership' of the sperm he had produced at the time of the defendant's negligence? The appeal court framed the issue as being 'whether sperm is capable of being owned' (ref. ${ }^{1}$, para28); and at no point in its judgment is question (3) or question (4) expressly identified. Now, the answers to the first two questions are logically related to the answers to (3) and (4). For instance, on the reasonable assumption that an object is 'owned' for the purposes of (1) if and only if someone has, in relation to it, something that counts as 'ownership' for the purposes of (4), an affirmative answer to (4), if true, entails an affirmative answer to (1). Conversely, if sperm is not capable of being 'owned' at all, then, granted the aforementioned assumption, the men did not have 'ownership' of it. But one can consistently give an affirmative answer to (1) and a negative answer to (4); the considerations bearing on these respective questions are not the same and so it is important not to conflate them. There is reason to suspect that the court's failure to expressly identify (4) is related to its peculiar account of 'ownership' (see below).

The trust claimed that the provisions of the 1990 Act prevented sperm from being a potential object of ownership, and that, on the basis of the rule stated by Lord Brandon, the men were not entitled to sue in negligence for 'damage to or loss of property'. For the purposes of this argument, the trust's lawyers referred to Professor Honoré's well-known account of ownership and argued that the 1990 Act had so restricted or excluded each of the 11 incidents that according to Honoré are present in the paradigmatic case of ownership that the sperm was not capable of being owned. ${ }^{7}$ Judge Griggs accepted this argument. ${ }^{8}$ The Court of Appeal disagreed. It accepted that the men could not direct that their sperm be used in a certain way, but stated that this did not 'derogate from their ownership' because: (1) there are numerous statutes that limit a person's ability to use his property without eliminating his ownership; and (2) the Act, through its provisions for consent, assiduously preserves the ability of the men to direct that the sperm not be used in a certain way: each had 'absolute negative control' over the sperm he had produced (ref. ${ }^{1}$, para45(f)).

In determining whether or not the claimants had 'ownership' of the samples, the court took a 'contextual' approach: '[a] decision whether something is capable of being owned...must be reached in context'; and here 'the context is whether an action in tort may be brought for loss of the sperm consequent upon breach of the trust's duty to take reasonable care of it' (ref. ', para28). The court took the view that 'in deciding whether sperm is capable of being owned for [that] purpose', part of its inquiry 'must be into the existence or otherwise of a nexus between the incident of ownership most strongly demonstrated on the facts of the case', namely, the limited right that each man had to use the sperm he had produced, and 'the nature of the damage consequent upon the defendant's breach of the duty of care': the preclusion of use (ref. ${ }^{1}$, para28). In line with this 'contextual' approach, the court concluded that each man had, for the purposes of his claims in negligence, ownership of his sample(s) (ref. 1, para45(f)). The court's justification for this conclusion consisted of five points that may be summarised as follows:

1. The men 'alone', '[b]y their bodies', had 'generated and ejaculated the sperm' (ref. ${ }^{1}$, para45(f)).

2. '[T] he sole object of their ejaculation of the sperm was that it might later be used for their benefit'. The men had 'rights to use' their sperm, albeit severely limited by legislation. But the legislation 'preserves the ability of the men to direct that the sperm be not used in a certain way': the men had 'absolute' 'negative control' (ref. ' ${ }^{1}$, para45(f)).

3. 'Ancillary to the object of later possible use of the sperm, is the need for its storage in the interim'; and, during that time, the men had absolute negative control, including the power to place the trust under an obligation to destroy the sperm (ref. ${ }^{1}$, para45(f)).

4. The licence-holder has duties, but 'no person other than each man had any rights in relation to the sample he had produced' (ref. ${ }^{1}$, para45(f)).

5. There was a 'precise correlation' between, on the one hand, 'the primary, if circumscribed, rights of the men in relation to the use of the sperm', and, on the other, 'the consequence of the trust's breach of duty, namely the preclusion of its use' (ref. ${ }^{1}$, para45(f)).

\section{CRITICAL ANALYSIS OF THE COURT'S REASONING Ownership in general and ownership in English law}

The Court of Appeal considered in detail the argument that the 1990 Act had so excluded or limited the rights that the men could have in relation to the sperm that they could not have had ownership of it. This is not surprising since the argument was accepted by Judge Griggs and the appeal court ultimately rejected it. But the whole discussion rests on faulty foundations. The defendant's argument relied upon Honorés account of ownership. But neither Judge Griggs nor the Court of Appeal questioned the presupposition that if the men could not have the sort of ownership described by Honoré, then they could not have legal ownership or possessory title for the purposes of the rule stated by Lord Brandon. That presupposition should be doubted even if it is accepted that Honoré's account of ownership is a successful one. Honoré's account of ownership is not an account of ownership in any particular legal system but of ownership as a 'type of interest with common features transcending particular systems' (ref. ${ }^{7}$, p.162). His account is philosophical; it is general and abstract. It is not a necessary truth that in order to have legal ownership or possessory title for the purposes of an action in negligence, one must actually have ownership. This is only to point out that an account of legal ownership and/or possessory title in English law is not an account of ownership as such. In order to identify when and whether a person has 'legal ownership or possessory title' for the purposes of a rule of English law, one must turn to the Law 
Reports, not (or not simply) recline in the philosopher's armchair.

The court stated that 'the concept of ownership is no more than a convenient global description of different collections of rights held by persons over physical and other things' (ref. ${ }^{1}$, para28). If by 'the concept of ownership' the court meant 'legal ownership and possessory title', the assertion should have been supported by references to, and discussion of, legal authorities. What are these different collections of rights over things that are described by 'ownership'? The court does not say. The court's views on ownership, insofar as they are about legal ownership and possessory title, suggest that these notions are rather mysterious. But they are not. A good account of (say) legal ownership is one that (1) explains how and when it is acquired (ie, the conditions that must be satisfied for a person to acquire legal ownership of a particular (type of) thing); (2) explains how it is lost (ie, the conditions by which persons who have legal ownership of a particular (type of) thing cease to have that ownership); and (3) explains the legal consequences that attach to it, especially the powers, rights, duties and/or immunities that the law regards as grounded by legal ownership. The court should have attended to some of the consequences that the law attaches to legal ownership and possessory title, namely, the consequence at issue (i.e. the duty or duties not to negligently damage the object of such a right), and to other consequences insofar as is necessary when determining whether the claimants were indeed owed such a duty or duties.

In the court's view, what consequences followed from the vesting of legal ownership or possessory title in the men? Is its view correct? And, in light of those consequences, did it properly justify its conclusion that the men had 'ownership' of the sperm? This brings us to the five points that the court advanced in support of its conclusion that the men had 'ownership' of the sperm they had produced for the purposes of their claims in negligence.

\section{The court's justification}

On one view, the appeal court thought that the men's 'absolute negative control' constituted them owners of the sperm. The view taken here is that the men's 'absolute negative control' was simply one aspect of the court's 'justification' for its conclusion that the men had 'ownership' for the purposes of their claims against the trust. This reliance on the men's 'absolute negative control' does, however, have an important limiting effect on the scope of the decision. The men's 'absolute negative control', the men's rights and the trust's duties to the men, were a consequence of the fact that the men had stored the sperm with the defendant trust; and the importance that the appeal court attached to that control means that fact must be regarded as material to the decision. A person does not ordinarily have such control over his or her gametes, and in the absence of such control, he or she will not on the basis of Yearworth have 'ownership' of it. As said, the court was not concerned only with the men's 'absolute negative control'. In order to understand the court's reasoning and the nature of the right that their Lordships concluded the men had, we must attend to the justification in full.

It is important that the court's justification is interpreted in light of the judgment as a whole. In this connection, notice the salience of all five points, but especially (5), to the court's focus on the 'context'. The question was not whether the men had 'ownership' of the sperm per se, but whether they had 'ownership' of it for the purposes of a claim in tort 'for loss of the sperm consequent upon breach of the trust's duty to take reasonable care of it' (ref. ${ }^{1}$, para28). Note also that (2)-(5) state, among other things, the results of the inquiry that the court, earlier in its judgment, said it must undertake in determining whether sperm is capable of being 'owned' in that context, namely, an inquiry into whether there was a nexus between the right that each man had to use the sperm and the consequences of the trust's breach of its duty of care. The conclusion of that inquiry, expressed in (5), was that there was indeed such a nexus. The court's justification is one that refers to and relies on the claimants' rights and the defendant's duties under the 1990 Act, and on the consequences of the defendant's breach of duty. What was that duty of care based on? The defendant admitted that it owed each of the men a duty of care in relation to the sperm and that it had breached those duties; and the Court of Appeal referred to these as 'important if inevitable admissions' (ref. ' ${ }^{1}$, para13). Those 'duties of care' were not a consequence of any property rights in the men. Presumably, they were based on the facts that the men were the defendant's patients; that the defendant had offered to store the sperm so that the men could later use it for their benefit and that the defendant had in fact stored the sperm on that basis, etc. The admission that the defendant had breached those duties of care did not amount to an admission of a legal wrong: it was an admission that they acted carelessly, unreasonably, but not tortiously. This is to say that the duty violation of which amounts to a tort (and so an actionable legal wrong) is not simply a duty to take reasonable care, but a duty not to cause particular kinds of damage by one's lack of reasonable care. ${ }^{9}$

Now what is the significance of the fact that the court, in framing the inquiry that it believed it had to pursue to determine whether the men had 'ownership' for the purposes of their claims and in stating the outcome of that inquiry in (5), referred to and relied on the consequences of the defendant's breach of its duty (or duties) of care? It could be argued that in (5) the court is not concerned with the defendant's breach of duty per se, but with its effect on each claimant, his plans and his rights to use the sperm. One could say that the material point was that the defendant's acts precluded the men from using the sperm, not that those acts amounted to a violation of the defendant's duty of care.

Perhaps that is so, but the court's statement that its decision as to whether the men had 'ownership' had to be reached in 'context', and its references to (A) the defendant's 'breach of duty' and (B) to the claimants' rights (against the defendant) and the defendant's duties under the 1990 Act, suggest that the court intended to confine its decision that the men had 'ownership' to the 'context', the context being the men's 'action[s] in tort...for loss of the sperm consequent upon breach of the trust's duty to take reasonable care of it.' In other words, those considerations suggest that the conclusion that the men had 'ownership' for the purposes of their claims against the defendant was not a deduction from or an incident of the more general statement that they had legal ownership or possessory title for the purposes of a claim in negligence. Rather, the conclusion was confined to those particular purposes, to those specific claims. The court saw its decision on what can be called the 'ownership question' as confined to the 'context.' Its reasoning, accordingly, pertains to whether the men had 'ownership' vis-à-vis the defendant trust, and, read in light of the judgment as a whole, presupposes that the men could have had 'ownership' against the defendant and only against the defendant. The court did not assert that persons other than the trust owed the men certain duties. According to the interpretation sketched here, it did not think it had to decide, and did not take itself to 
be deciding, that issue. In other words, the court decided that the men had 'ownership' (for the purposes of the tort of negligence) against the trust; that the men's 'ownerships' grounded duties of a certain kind on the trust. But the court was only going as far as to say that they had 'ownership' against the trust such that the trust (but no other) owed the men a duty not to cause, by its negligence, damage to the sperm that would preclude the men from using it.

In matters of interpretation there are often no knock-down arguments. But I think the interpretation advanced in the preceding paragraph should be taken seriously. For if the foregoing is right, it is easy to see why many have found the court's judgment to be unconvincing and incomplete. Dr Harmon and Professor Laurie have written that 'the conceptual foundation of the Court's finding of a (new) property interest is not entirely clear' (ref. ${ }^{3}$, p.485); and that 'the Court failed to ground its finding of property' (ref. ${ }^{3}, \mathrm{p} .486$ ). But, on the basis of the interpretation advanced above, the court did not regard itself as establishing a 'new property interest' at all, at least not if by property we mean a right in rem, a right 'binding the world'. iii The court's justification is tailored to the question it thought it had to answer-Did each claimant have ownership or possessory title for the purposes of his claim in negligence against the Trust? - and conditioned by the idea that the claimants could have 'ownership' only for the purposes of their claims, and by the thought that in determining whether the claimants had such 'ownership' it could look to (among other things) the effect of the defendant's 'breach of duty' on the claimants' rights. If their Lordships were right to think that, then the reasoning underpinning their conclusion is not obviously implausible. The court did not ground a 'new property interest' because it did not regard the men as having such an interest. However, it did justify the claimants' 'ownerships' against the trust for the purposes of their claims against it, or so one could argue. Here, it may be said, lies the ingenuity of the court's approach: the court, by limiting each claimant's 'ownership' to 'ownership against the trust', interpreted the requirements of the rule stated by Lord Brandon in such a way as to reduce the complexity of the issue and to narrow the range of relevant considerations: it circumscribed the issue it had to decide by circumscribing 'ownership', by silently assuming that a person could have legal ownership or possessory title against a particular person only. ${ }^{\text {iv }}$

\section{Property rights and rights in rem}

The view that a person can have legal ownership or possessory title against a particular person only is one that any property lawyer is bound to find most strange. ${ }^{v}$ Property lawyers and theorists disagree about whether it is a necessary feature of a property right that it is a right in rem, a right that 'binds the world'. But many of those who doubt that it is, accept that it is a necessary and important feature of a class of property rights ${ }^{10}{ }^{11}$, and no doubt legal ownership and possessory title are often seen as clear examples of such rights.

What is a right in rem? According to Peter Birks, 'rights in rem are in principle demandable wherever the res (the thing) is

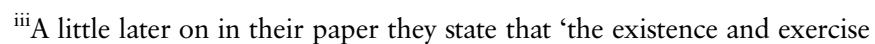
of the property right are in question'; but that claim seems to be based on different considerations.

${ }^{\text {iv }}$ All I can say here in relation to the court's decision that the sperm had been bailed is: one does not need a right in rem in order to be a bailor. 'But perhaps the idea doesn't appear strange to one who believes that legal ownership and possessory title are no more than 'convenient global description[s] of different sets of rights over things'.
}

found and hence against anyone who has it or is interfering with it' (ref. ${ }^{11}$, p.28). An alternative but related account of rights in rem (and one that may do further violence to the Latin) maintains that rights in rem are rights that ground duties on persons generally. John Austin said that the expression in rem, when annexed to the term right...points at the compass of the correlating duty. It denotes that the relative duty lies upon persons generally, and is not exclusively incumbent upon a person or persons determinates. In other words, it denotes that the right in question avails against the world at large. ${ }^{12}$ Note that, for Austin, a right that holds against persons generally is a right that holds against an indeterminate class of persons. Honoré has pointed out that, in fact, one could identify at any particular moment all persons bound, under the rules of a given system, by a particular right in rem if one had an adequate census and a record of visitors to the jurisdiction. ${ }^{13}$ What matters is not whether a right in rem holds against a determinate or indeterminate class of persons, but that it holds against 'persons generally', against 'the world at large'.

In Honoré's view ' $[t]$ he truth is that some duties or restrictions are imposed by the law on everyone subject to a given legal system except those who have an exemption or privilege' (ref. ${ }^{13}$, p.455); and 'a right protected by claims against all except those exempt or privileged is in rem' (ref. ${ }^{13}$, p.458). This account of a right in rem presupposes a distinction between 'rights' and 'claims', and the distinction Honoré drew between these has been convincingly criticised (ref. ${ }^{10}$, p.86). So, ignoring the distinction between rights and claims, one may say that a right in rem is a right that grounds duties on all except those exempt or privileged. ${ }^{\mathrm{vi}}$ One should not interpret this as meaning that there is an unchanging set of persons against whom rights in rem hold. As Honoré has explained, they persist through time and can survive changes in the identity of persons against whom they hold.

Campbell has criticised Honoré's account of rights in rem on the basis that it says 'no more than that rights in rem hold against everyone except those against whom they do not hold' (ref. ${ }^{10}$, p.87). But it seems to me that this is not all it says. On Honoré's account, all persons subject to a given legal system owe certain duties to the holder of a right in rem unless they are privileged or exempted. One way to interpret this is as meaning that a right in rem is a right that prima facie is sufficient reason for holding all persons to owe certain duties to the right-holder. I say 'prima facie' because in respect of certain persons or certain persons in certain circumstances the reasons that give rise to the right and that would otherwise justify these persons being obligated to act in a certain way or in certain ways in the interests of the right-holder are cancelled or overridden such that they are not obligated to so act. Where this is the case, these persons can be said to be 'privileged or exempted'. A legal right in rem is a right recognised by law that the law regards as prima facie grounding certain duties on all persons.

Whether one accepts the account of rights in rem put forward in the preceding paragraph or not, the important point is that, on any view, if the interpretation of the court's judgment advanced in the previous section is correct, the court denied that legal ownership and possessory title are necessarily rights in rem; and it did not hold that the men had rights in rem. Each man had 'ownership' against the trust and only against the trust.

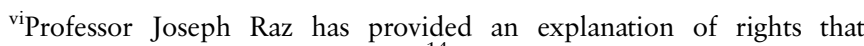
regards rights as grounding duties. ${ }^{14}$ Some of my remarks on rights in the text are based on Raz's work. 
The 'ownership' that the court regarded the men as having, then, could not be lawfully enforced against a stranger, and it did not ground duties on persons generally. If the court thought that the men had 'ownership' against the trust only, we may infer that the court did not regard the men's 'ownerships' as (prima facie) sufficient reason for holding all persons to owe the men certain duties. So on the basis of the interpretation advanced above, the 'ownership' that the court regarded the men as having was not a right in rem; and, on a narrow view of property rights, it was not a property right.

Even if the foregoing is sound, the conclusion that the men had rights in rem may be forced upon us (and the courts). The relevant principle is the one that provides that judgments must be interpreted in light of other judgments. This is an important principle: it places certain limits on the extent to which a judge or judges sitting in a particular case can alter the law. If legal ownership and possessory title must, as a matter of law, be rights in rem, or if one must have a right in rem in order to sue for property damage or destruction in negligence, then the men could not have had legal ownership or possessory title against the trust only and the Court of Appeal's approach cannot stand.

\section{CONCLUSION}

The upshot may be that we must regard Yearworth as establishing that in English law persons have, in certain narrow circumstances, a right in rem in their sperm, a right grounding duties on persons generally not to cause by their negligence such damage to the sperm as would preclude the right-holder(s) from using it. But if that is the true position, it is far from ideal: for the Court of Appeal did not decide that the men in Yearworth had rights grounding certain duties on persons generally and did not intend to establish that in English law persons acquire, in certain circumstances, rights in rem in their sperm. At least, that is the case according to the interpretation of the court's judgment advanced above; an interpretation that is, I think, plausible and defensible.

\section{Competing interests None.}

Provenance and peer review Not commissioned; externally peer reviewed.

\section{REFERENCES}

1 Yearworth and Others v North Bristol NHS Trust [2009] EWCA Civ 37, [2010] QB 1.

2 Quigley M. Property: the future of human tissue. Med Law Rev 2009;17:457-66.

3 Harmon SHE, Laurie G. Yearworth v North Bristol NHS trust: property, principles, precedents and paradigms. Cambridge Law J 2010;69(3):476-93.

4 Pawlowski M. Property in body parts and products of the human body. Liverpool Law Rev 2009;30:35-55.

5 Hawes C. Property interests in body parts: Yearworth v North Bristol NHS trust. Mod Law Rev 2010;73:130-40:139.

6 Leigh \& Sullivan Ltd v Aliakmon Shipping Co Ltd [1986] AC 785:809E.

7 Honoré AM. Ownership. In: Honoré AM, ed. Making law bind: essays legal and philosophical. Oxford: Clarendon Press, 1987: 161-92.

8 [2008] LS Law Medical 535:para 153.

9 Gardner J. Obligations and outcomes in the law of torts. In: Cane P, Gardner J, eds. Relating to responsibility: essays for Tony Honoré. Oxford: Hart Publishing, 2001: 111-43:122.

10 Campbell K. On the general nature of property rights. King's Coll Law J 1992;3:79-97.

11 Birks P. Unjust enrichment. 2nd edn. Oxford: Oxford University Press, 2005: 29

12 Austin J. The province of jurisprudence determined. London: J Murray, 1832: xxviii.

13 Honoré AM. Rights of exclusion and immunities against divesting. Tulane Law Rev 1959-60;34:453-68:455.

14 Raz J. The nature of rights. In: The morality of freedom. Oxford: Oxford University Press, 1986: 165-92. 